\title{
1 Rainforest-like atmospheric chemistry in a polluted megacity
}

2

5

6

7

8
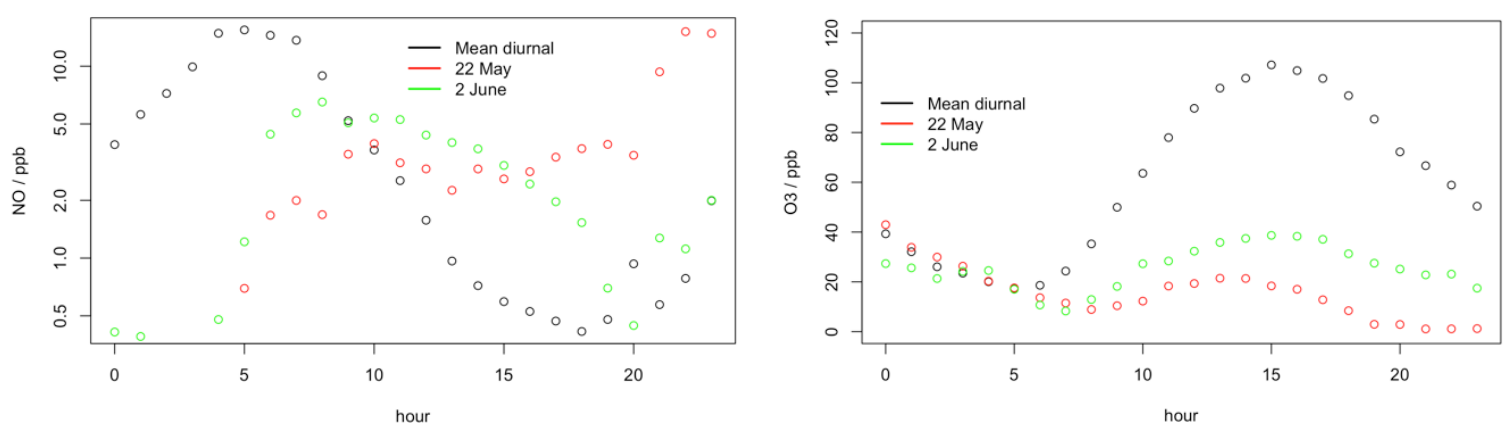

Figure $\mathrm{S} 1$ Comparison of mean diurnal cycle of $\mathrm{NO}$ and $\mathrm{O}_{3}$ during typical high ozone days with the atypical days 22 May and 2 June. The full time series have been filtered for days with afternoon ozone peaks $<70 \mathrm{ppb}$. 


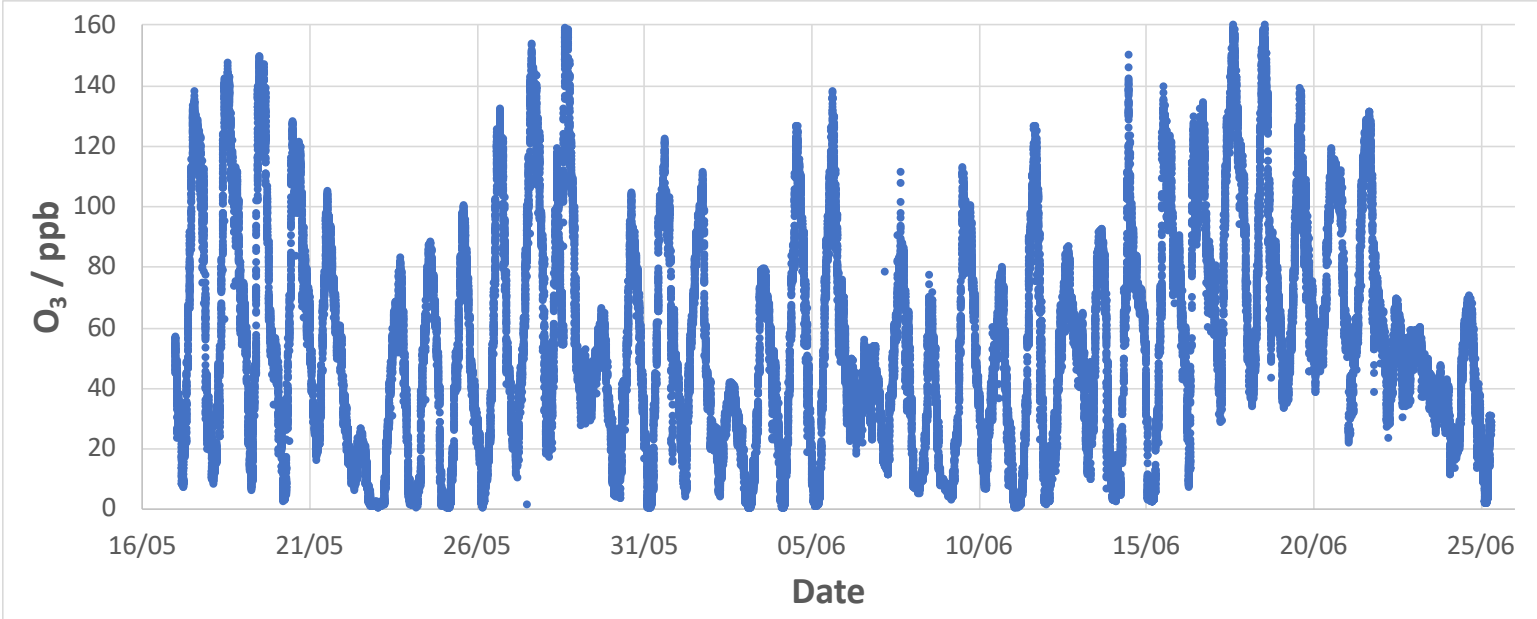

30

Figure S2 Ozone time series for the campaign. 17 May - 25 June.

31

32

33

34

35

36

37

38

39

40

41

42

43

44

45

46

47

48

49

50

51

52

53

54

55

56

57

58

59

60

61 

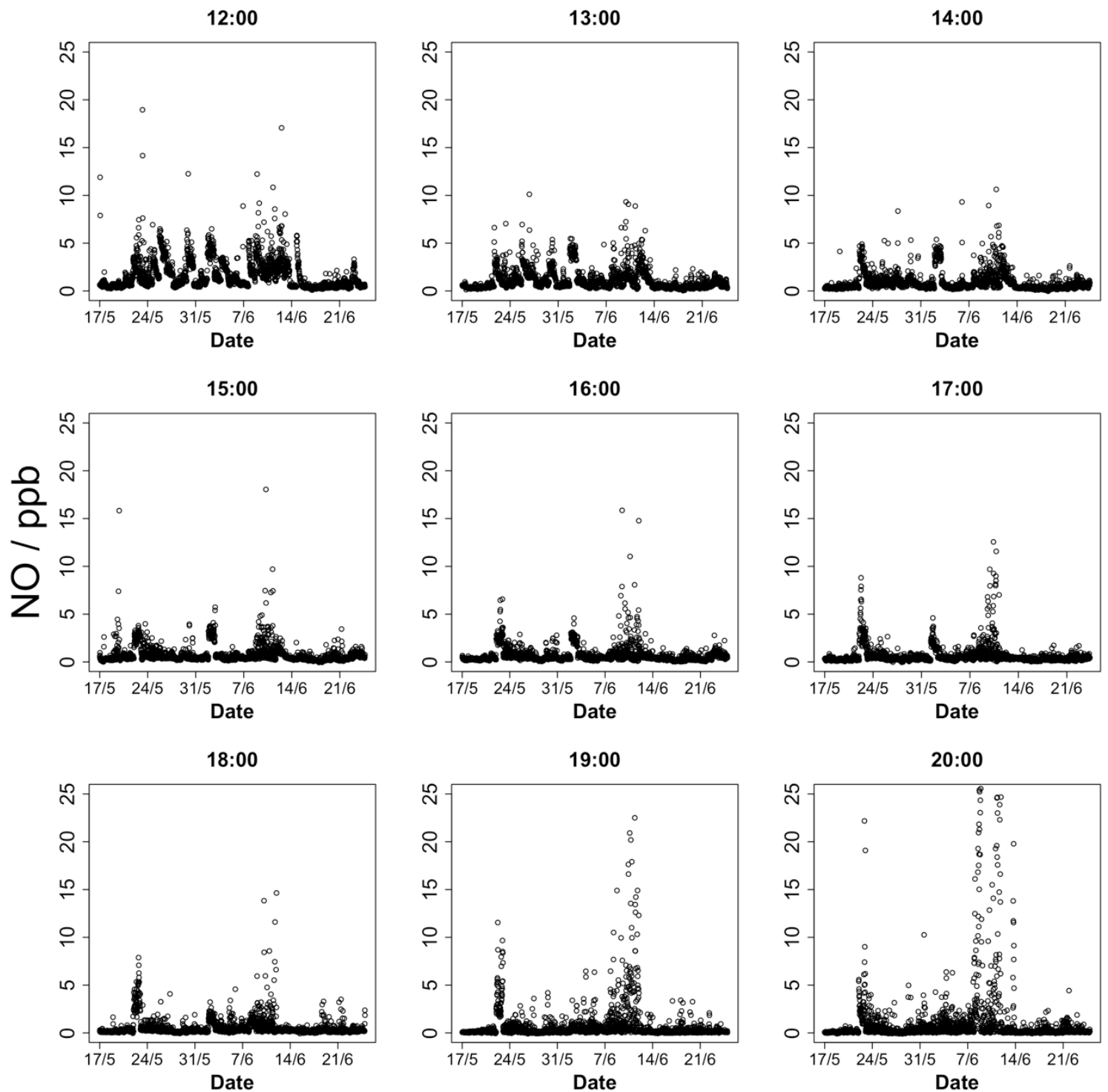

64

67

68

69

70

Figure S3 NO measurements for each hour between 12:00 and 20:00 for the duration of the campaign. Measurements at 1 minute frequency, i.e. 60 per day.

Figure S4 shows the mean hourly measurements of NO for each day of the campaign. A red dashed line between $12: 00$ and 20:00 represents the $N O$ mixing ratio at which $f_{N O}=0.75$, i.e. $25 \%$ of ISOPOO is not reacting with $\mathrm{NO}$, based on the mean hourly $\mathrm{OH}$ and $\mathrm{OH}$ reactivities for the whole campaign. 


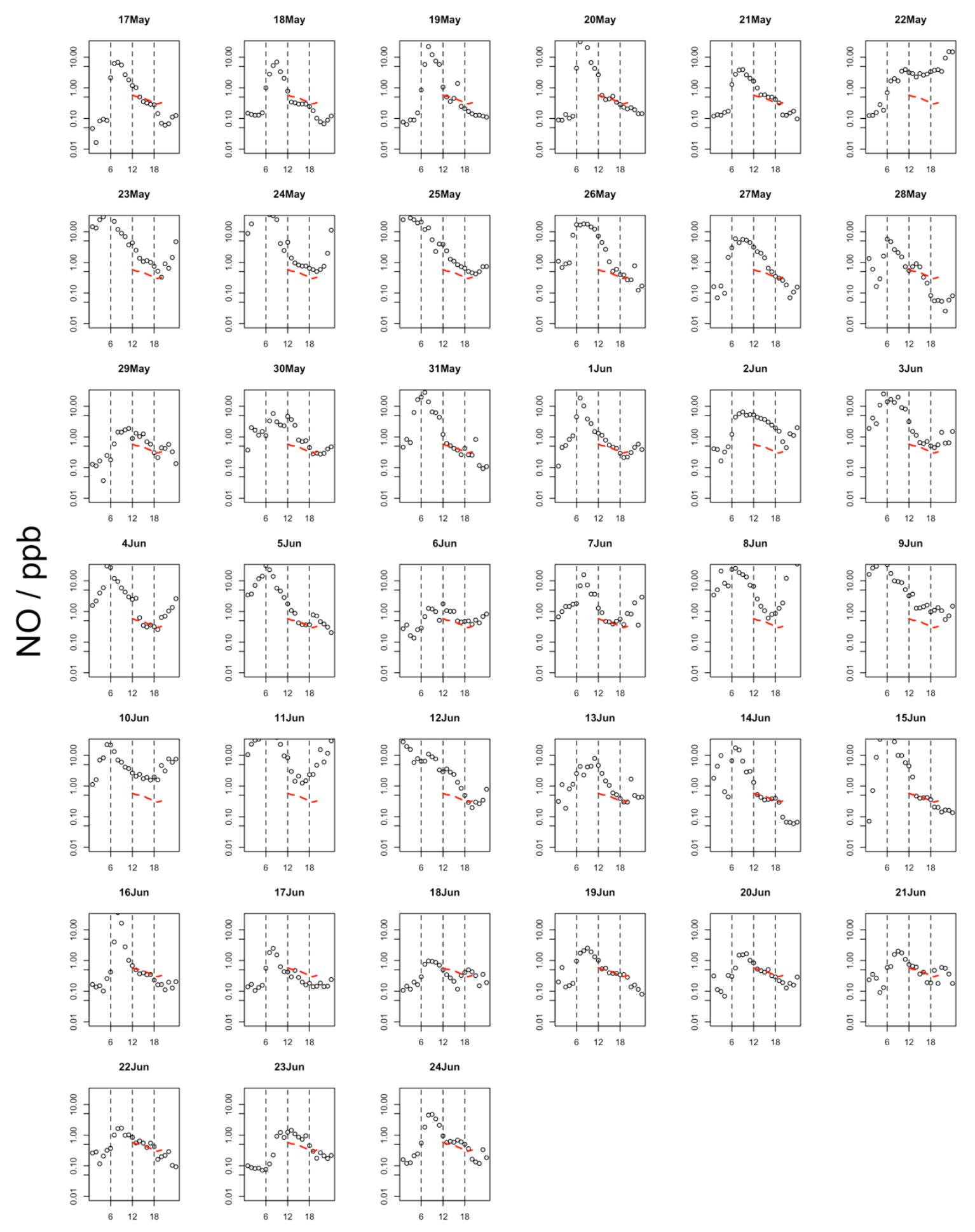

Hour

Figure S4 Mean hourly measured NO mixing ratios (ppb) during the campaign. Red dashed line between 12:00 and 20:00 represents the $\mathrm{NO}$ mixing ratio at which $<75 \%$ of $\mathrm{RO}_{2}$ are calculated to be reacting with NO. 
82

83 Figure 3 in the main manuscript plots measured values of $[\mathrm{OH}] \times \mathrm{OH}$ reactivity* against [NO]

84 between 12:00 and 20:00 for campaigns across a range of different environments. Only field 85 campaigns where both $\mathrm{OH}$ and $\mathrm{OH}$ reactivity were measured can be plotted on Figure 3 (see

86 Table S1) and the variability in NO levels in these regions is likely to be greater. For the Beijing 87 dataset, the hourly median values of [NO] are used (Figure S5), with the 9 'atypical' chemistry 88 days (as defined above) removed. Figure S5 shows the NO measurements for each hour 89 between 12:00 and 20:00 for the whole campaign (excluding the 9 'atypical chemistry days) 90 binned into $50 \mathrm{ppt}$ bins between 0 and $1000 \mathrm{ppt}$. The median value takes into account all of 91 the measurements including those above 1000 ppt not shown. 

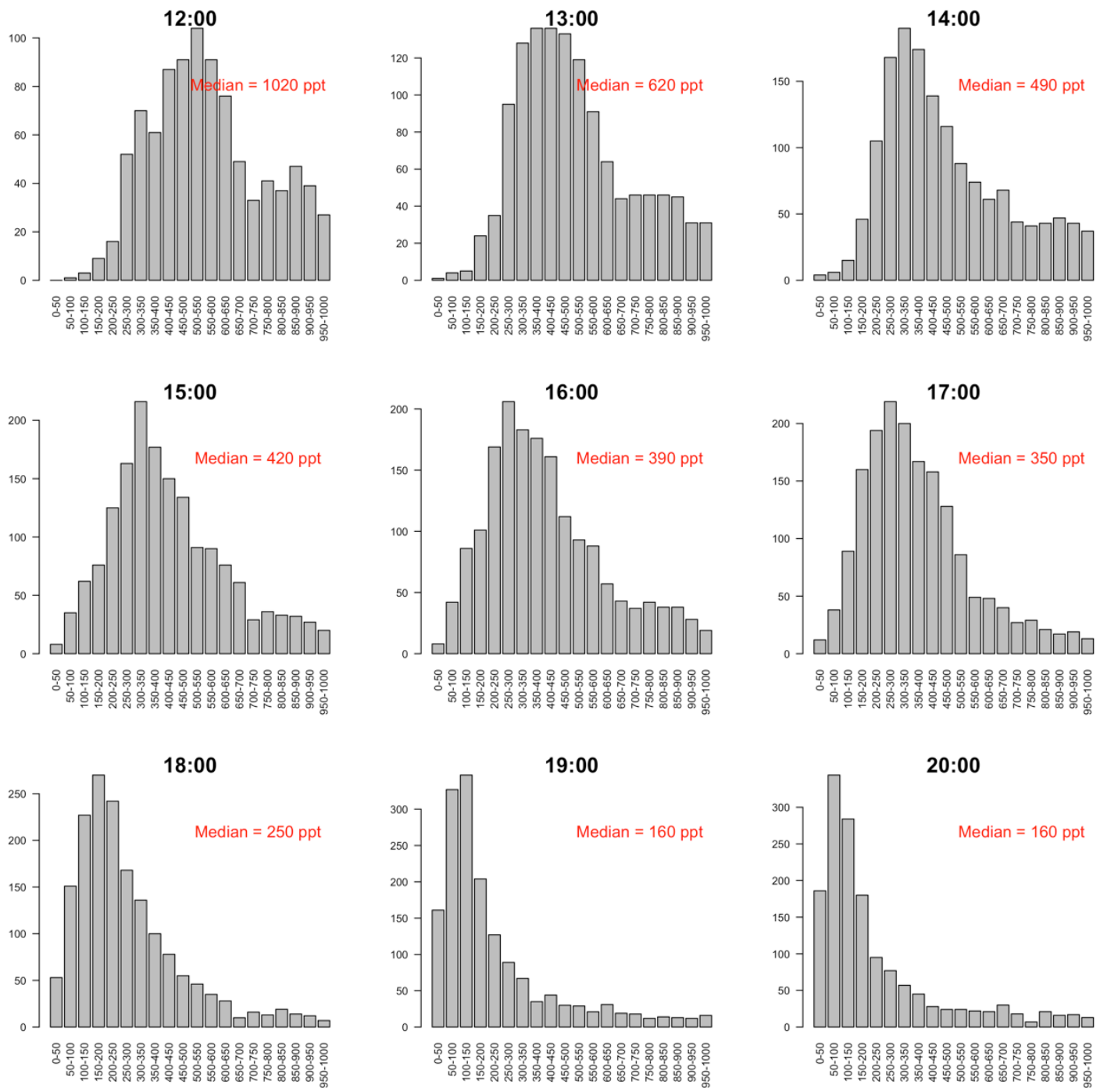

Figure S5 Distribution of minute averaged NO mixing ratios (ppt) during the campaign split in to 50 ppt bins for the hours 12:00 - 20:00, excluding the nine atypical days (see 'Filtering data for diurnals' above).

96 
105

106

109

110

111

112

\section{Modelling approach}

\section{Box modelling}

115 Table S2 Dry deposition velocities applied to all species based on their functional groups 116

Table S1 Details of measurement locations and conditions presented in Figure 3.

\begin{tabular}{|c|c|c|c|c|}
\hline Location & Campaign & Date & $\begin{array}{l}\mathrm{HO}_{\mathrm{x}} \text { and } \mathrm{OH} \text { reactivity } \\
\text { measurements } \\
\text { Inlet position }\end{array}$ & Reference \\
\hline $\begin{array}{c}\text { NEW YORK } \\
\text { Queens College, } \\
\text { Borough of Queens } \\
\left(40^{\circ} 44^{\prime} 15^{\prime \prime} \mathrm{N}\right. \\
\left.73^{\circ} 49^{\prime} 18^{\prime \prime} \mathrm{W}\right)\end{array}$ & $\begin{array}{l}\text { PMTACS - } \\
\text { NY2001 }\end{array}$ & $\begin{array}{c}\text { June - } \\
\text { August } 2001\end{array}$ & $\begin{array}{c}\text { Co-located } \\
\text { Scaffolding Tower at } 6.4 \mathrm{~m} \\
\mathrm{~T}=279-308 \mathrm{~K} \\
\text { Average } \mathrm{RH}=55 \%\end{array}$ & $\begin{array}{l}\text { Ren et al. } \\
\text { (2003) }\end{array}$ \\
\hline $\begin{array}{c}\text { BORNEO } \\
\text { Burkit Atur GAW } \\
\text { Station, } \\
\text { Sabah Region } \\
\left(4^{\circ} 58^{\prime} \mathrm{N}, 117^{\circ} 48^{\prime \prime} \mathrm{E}\right)\end{array}$ & OP3 - I & $\begin{array}{l}\text { April - May } \\
2008\end{array}$ & $\begin{array}{c}\text { Co-located } \\
\text { Container roof at } 5 \mathrm{~m} \\
\mathrm{~T}=295-300 \mathrm{~K}\end{array}$ & $\begin{array}{c}\text { Whalley et al. } \\
\text { (2011) }\end{array}$ \\
\hline $\begin{array}{c}\text { LONDON } \\
\text { Sion Manning School, } \\
\text { North Kensington } \\
\left(51^{\circ} 31^{\prime} 61^{\prime \prime} \mathrm{N},\right. \\
\left.0^{\circ} 12^{\prime} 48^{\prime \prime} \mathrm{W}\right)\end{array}$ & ClearfLo & $\begin{array}{l}\text { July - } \\
\text { August } \\
2012\end{array}$ & $\begin{array}{c}\text { Co-located } \\
\text { Container roof at } 3.5 \mathrm{~m} \\
\mathrm{~T}=285-300 \mathrm{~K}\end{array}$ & $\begin{array}{l}\text { Whalley et al. } \\
\text { (2016) }\end{array}$ \\
\hline $\begin{array}{c}\text { ALABAMA } \\
\text { Centreville Research } \\
\text { Site, } \\
\text { Brent, SE - US } \\
\left(32^{\circ} 54^{\prime} 11.81^{\prime \prime} \mathrm{N}\right. \\
\left.87^{\circ} 14^{\prime \prime} 59.79^{\prime \prime} \mathrm{W}\right)\end{array}$ & SOAS & $\begin{array}{l}\text { June - July } \\
2014\end{array}$ & $\begin{array}{c}\text { Co-located } \\
\text { Tower at } 15 \mathrm{~m} \\
\mathrm{~T}=301-303 \mathrm{~K} \\
\mathrm{RH}=50-80 \%\end{array}$ & $\begin{array}{c}\text { Sanchez et al. } \\
(2018)\end{array}$ \\
\hline
\end{tabular}
based on Nguyen et al. (2015)

\begin{tabular}{ll}
\hline $\begin{array}{l}\text { Functional group / } \\
\text { species }\end{array}$ & $\begin{array}{l}\text { Dry deposition velocity } \\
\left(\mathrm{cm} \mathrm{s}^{-1}\right)\end{array}$ \\
\hline Hydroperoxide & 2.0 \\
$\mathrm{H}_{2} \mathrm{O}_{2}$ & 5.2 \\
Organic nitrate & 2.0 \\
$\mathrm{HNO}_{3}$ & 3.8 \\
$\mathrm{Organic}$ & 1.0 \\
Oxygenated & 1.2 \\
Other & 0.1 \\
\hline
\end{tabular}


119 Figure $\mathrm{S} 6$ shows the amount of ISOPOO reacting with $\mathrm{NO}\left(f_{\mathrm{NO}}\right), \mathrm{HO}_{2}\left(f_{\mathrm{HO}}\right), \mathrm{RO}_{2}\left(f_{\mathrm{RO}}\right)$, or 120 isomerising $\left(f_{\text {Iso }}\right)$, for four different model runs with different fixed concentrations of $\mathrm{C}_{5} \mathrm{H}_{8}$ (i.e. $121 \mathrm{OH}$ reactivity) and $\mathrm{OH}$. The point at which the contributions of the $\mathrm{NO}\left(f_{\mathrm{NO}}\right)$ and $\mathrm{HO}_{2}\left(f_{\mathrm{HO}}\right)$ 122 channels are equal increases with increasing $[\mathrm{OH}]$ and with increasing $\mathrm{OH}$ reactivity, as shown 123 in Figure 3 of the main manuscript. Figure $\mathrm{S} 7$ shows the modelled $\mathrm{HO}_{2}$ and $\mathrm{RO}_{2}$ concentrations 124 for the same four model runs. As expected, both $\mathrm{HO}_{2}$ and $\mathrm{RO}_{2}$ increase with increasing [OH] 125 and $\mathrm{OH}$ reactivity - this leads to the observed changes in $f_{\mathrm{NO}}$ and $\boldsymbol{f}_{\mathrm{HO}}$ in Figure S6. At very low $126[\mathrm{NO}](<20 \mathrm{ppt}),\left[\mathrm{RO}_{2}\right]>\left[\mathrm{HO}_{2}\right]$, although $\mathrm{HO}_{2}$ dominates the reaction of ISOPOO because $127 k\left(\right.$ ISOPOO $\left.+\mathrm{HO}_{2}\right)>>\left(\right.$ ISOPOO $\left.+\mathrm{RO}_{2}\right)$ (Jenkin et al., 2015). As [NO] increases, [RO $]$ falls 128 rapidly, with $\left[\mathrm{HO}_{2}\right]$ falling less rapidly and becoming greater than $\mathrm{RO}_{2}$. 


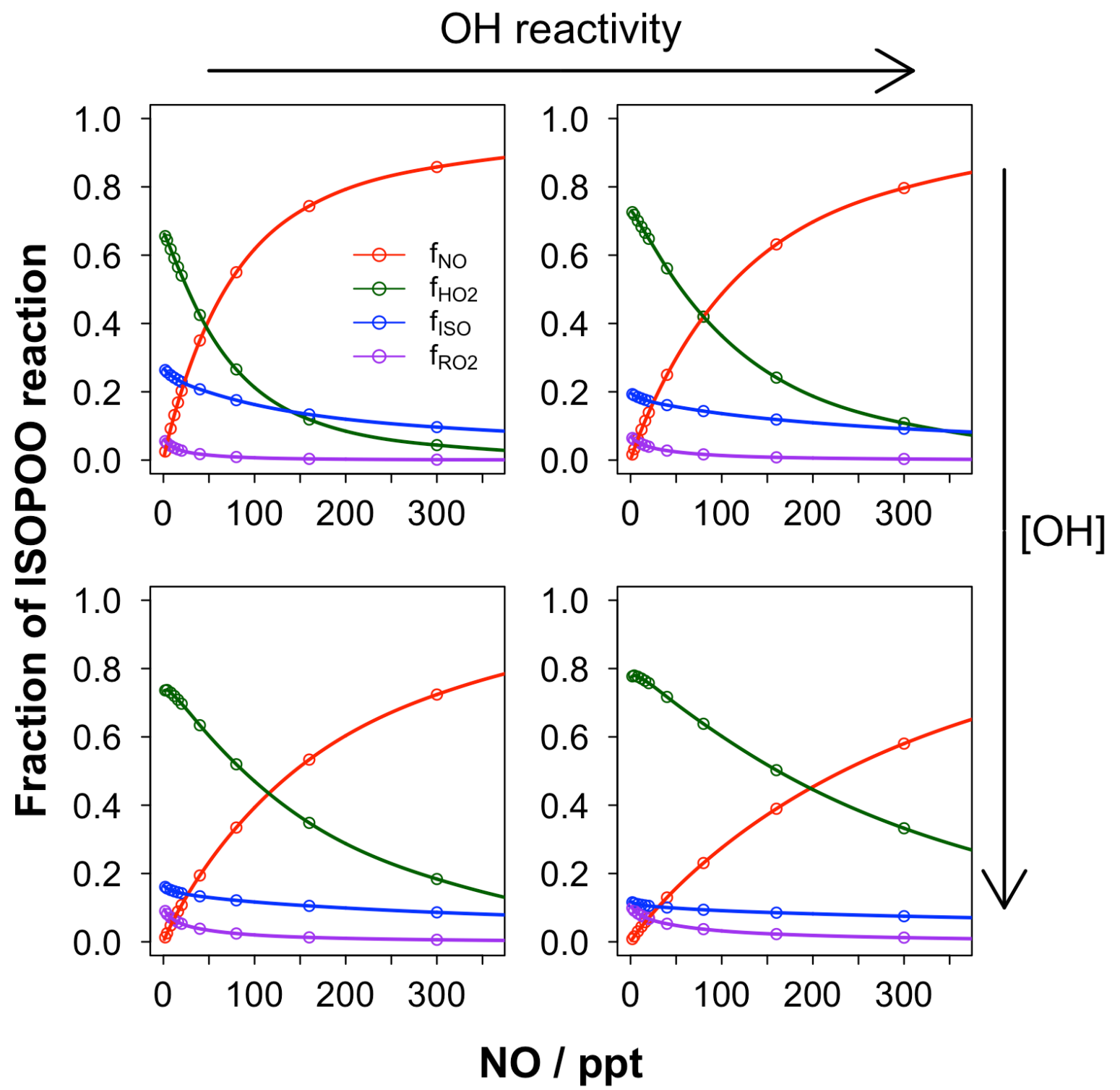

Figure $\mathbf{S 6}$ Example of model output showing the fraction of ISOPOO reacting with $\mathrm{NO}\left(f_{\mathrm{NO}}\right), \mathrm{HO}_{2}\left(f_{\mathrm{HO}_{2}}\right), \mathrm{RO}_{2}\left(f_{\mathrm{RO} 2}\right)$, or isomerising $\left(f_{\text {Iso }}\right)$, for four different model runs. Top left: $\left[\mathrm{C}_{5} \mathrm{H}_{8}\right]=1.7 \mathrm{ppb},[\mathrm{OH}]=5 \times 10^{5} \mathrm{~cm}^{-3}$; Top right: $\left[\mathrm{C}_{5} \mathrm{H}_{8}\right]=5.0 \mathrm{ppb}$, $[\mathrm{OH}]=5 \times 10^{5} \mathrm{~cm}^{-3}$; Bottom left: $\left[\mathrm{C}_{5} \mathrm{H}_{8}\right]=1.7 \mathrm{ppb},[\mathrm{OH}]=3 \times 10^{6} \mathrm{~cm}^{-3}$; Bottom right: $\left[\mathrm{C}_{5} \mathrm{H}_{8}\right]=5.0 \mathrm{ppb},[\mathrm{OH}]=3 \times 10^{6} \mathrm{~cm}^{-3}$ 


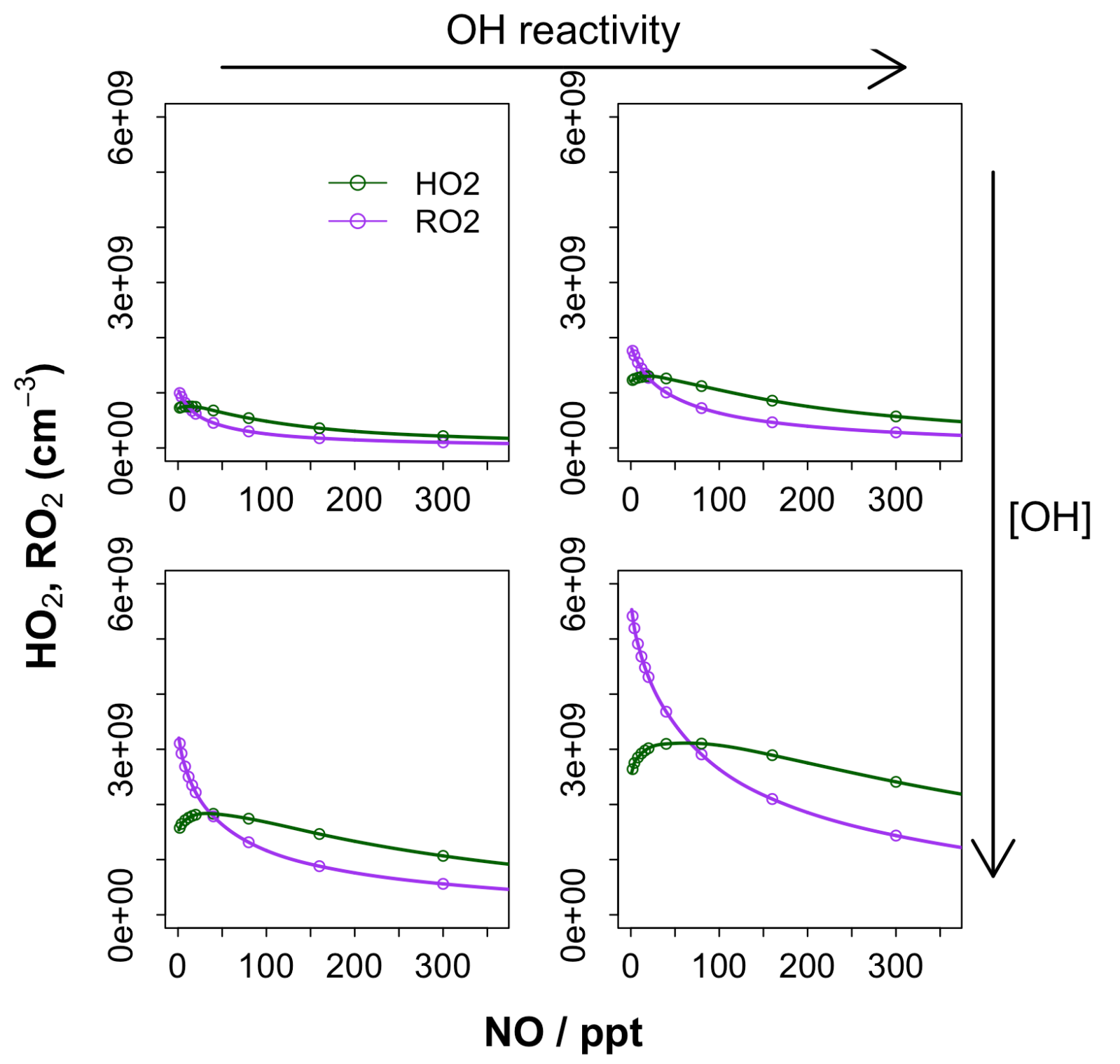

Figure S7 Example of model output showing modelled $\left[\mathrm{HO}_{2}\right]$ and $\left[\mathrm{RO}_{2}\right]$ for the four model runs shown in Figure S6. Top left: $\left[\mathrm{C}_{5} \mathrm{H}_{8}\right]=1.7 \mathrm{ppb},[\mathrm{OH}]=5 \times 10^{5} \mathrm{~cm}^{-3}$; Top right: $\left[\mathrm{C}_{5} \mathrm{H}_{8}\right]=5.0 \mathrm{ppb},[\mathrm{OH}]=5 \times 10^{5} \mathrm{~cm}^{-3}$; Bottom left: $\left[\mathrm{C}_{5} \mathrm{H}_{8}\right]=1.7 \mathrm{ppb},[\mathrm{OH}]=3$ $\times 10^{6} \mathrm{~cm}^{-3}$; Bottom right: $\left[\mathrm{C}_{5} \mathrm{H}_{8}\right]=5.0 \mathrm{ppb},[\mathrm{OH}]=3 \times 10^{6} \mathrm{~cm}^{-3}$ 
146 The $\mathrm{x}$-axis of Figure 3 in the main manuscript is $\mathrm{OH} x \mathrm{OH}$ reactivity*, where $\mathrm{OH}$ reactivity* is

147 defined as the $\mathrm{OH}$ reactivity attributable to VOCs (Equation E1) - i.e. without contributions

148 from $\mathrm{OH}+\mathrm{NO}_{x}$ (as this reaction does not make any $\mathrm{RO}_{2}$ species). The total $\mathrm{OH}$ reactivity as a

149 function of [NO] from an example model run, for which $\left[\mathrm{C}_{5} \mathrm{H}_{8}\right]=3.4 \mathrm{ppb}$ and $[\mathrm{OH}]=1 \times 10^{6}$

$150 \mathrm{~cm}^{-3}$ is shown in Figure $\mathrm{S} 8$. The modelled $\mathrm{OH}$ reactivity is highest at low NO concentrations,

151 with the main contributions from isoprene hydroperoxides (produced from ISOPOO+HO

152 the parent $\mathrm{VOC}$ isoprene. At higher NO concentrations, the reactivity first decreases as

153 production of isoprene hydroperoxides decreases, at even higher NO concentrations, $\mathrm{OH}$

154 reactivity begins to increase again as contributions from $\mathrm{NO}$ and $\mathrm{NO}_{2}$ become important -

155 however these do not contribute to $\mathrm{OH}$ reactivity*. 


\section{$\mathrm{C} 5 \mathrm{H} 8=3.4 \mathrm{ppb}, \mathrm{OH}=1 \mathrm{e} 6$}

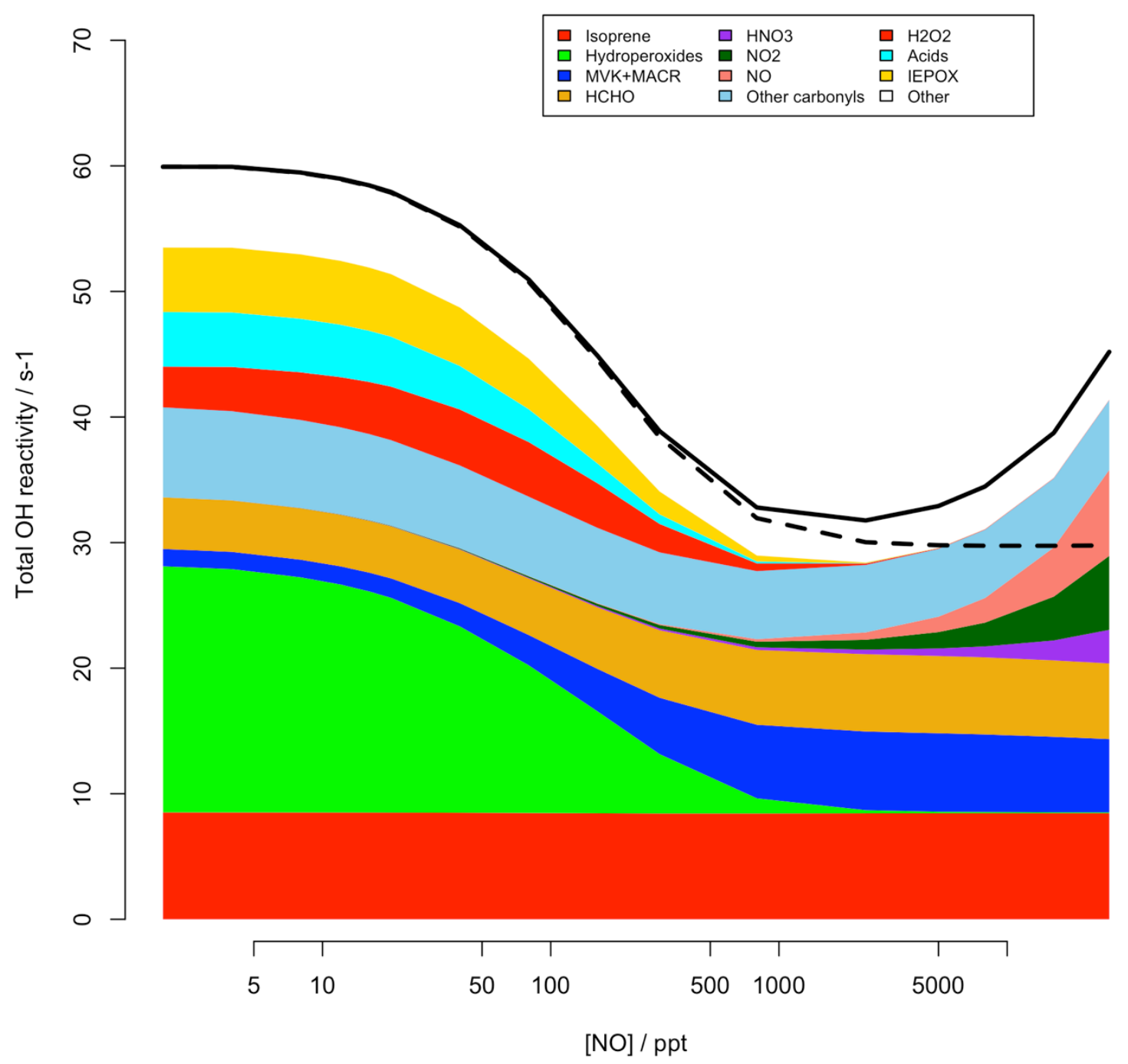

Figure $\mathbf{S 8}$ Modelled OH reactivity .v. [NO] for a model run initiated with $\left[\mathrm{C}_{5} \mathrm{H}_{8}\right]=3.4 \mathrm{ppbv},[\mathrm{OH}]=1 \times 10^{6} \mathrm{~cm}^{-3}$. Solid line is total $\mathrm{OH}$ reactivity. Dashed line is total $\mathrm{OH}$ reactivity*. 
175

176

177

178

179

180

181

182

183

184

185

186

187

188

189

190

191

192

193

194

195

196

197

\section{Fraction of $\mathrm{NO}$ reacting with other $\mathrm{RO}_{2}$}

The box modelling for Figure 3 in the main manuscript is initialised with isoprene as the only VOC. Hence ISOPOO are the main (non- $\mathrm{HO}_{2}$ ) $\mathrm{RO}_{2}$ and the reactivity is dependent on isoprene and its oxidation products. However, the conclusions on the fate of ISOPOO drawn from the modelling hold for any other peroxy radicals, with minor variations. The fraction of $\mathrm{RO}_{2}$ from a particular VOC that reacts with NO (i.e. $f_{\mathrm{NO}}$ ) is dependent on the ratio of its reaction rate with NO $\left(k_{\mathrm{NO}}\right)$ to the sum of all the loss processes (Equation ES1).

$$
f_{\mathrm{NO}}=\frac{k_{\mathrm{NO}}[\mathrm{NO}]}{k_{\mathrm{NO}}[\mathrm{NO}]+k_{\mathrm{HO}}[\mathrm{HO} 2]+k_{\mathrm{RO} 2}[\mathrm{RO} 2]+k_{I S O M}}
$$

In the MCM, $k_{\mathrm{NO}+\mathrm{RO} 2}$ is the same value for the majority of $\mathrm{RO}_{2}, 2.7 \times 10^{-12} \exp ^{(360 / \mathrm{TEMP})}=9.0 \times$ $10^{-12}$ (298K) (with the exception of acyl-RO $\mathrm{RO}_{2}$ for which it is $2.0 \times 10^{-11}$ (298K) (Jenkin et al., 1997; 2019)). The other possible major sink for $\mathrm{RO}_{2}$ under atmospheric conditions is reaction with $\mathrm{HO}_{2}$. $k_{\mathrm{HO} 2+\mathrm{RO} 2}$ varies with carbon number in the $\mathrm{MCM}$ tending towards a maximum value of $2.3 \times 10^{-11}(298 \mathrm{~K})$ (Jenkin et al., 1997)). Figure S9 shows the variation of $f_{\mathrm{NO}}$ as a function of [NO] for the initial $\mathrm{RO}_{2}$ derived from isoprene, $\mathrm{n}$-butane (a straight chain alkane), and toluene (an aromatic compound). $f_{\mathrm{NO}}$ follows the same trend for the $\mathrm{RO}_{2}$ from all three VOCs. For both $\mathrm{n}$-butane and toluene derived $\mathrm{RO}_{2}, f_{\mathrm{NO}}$ is a little higher than for ISOPOO. For the example of straight chain alkanes, as the size of the alkane increases, $f_{\text {NO }}$ would be expected to approach closer to the values for isoprene, as $k_{\mathrm{HO} 2+\mathrm{RO} 2}$ becomes faster while $k_{\mathrm{NO}+\mathrm{RO} 2}$ remains the same. 


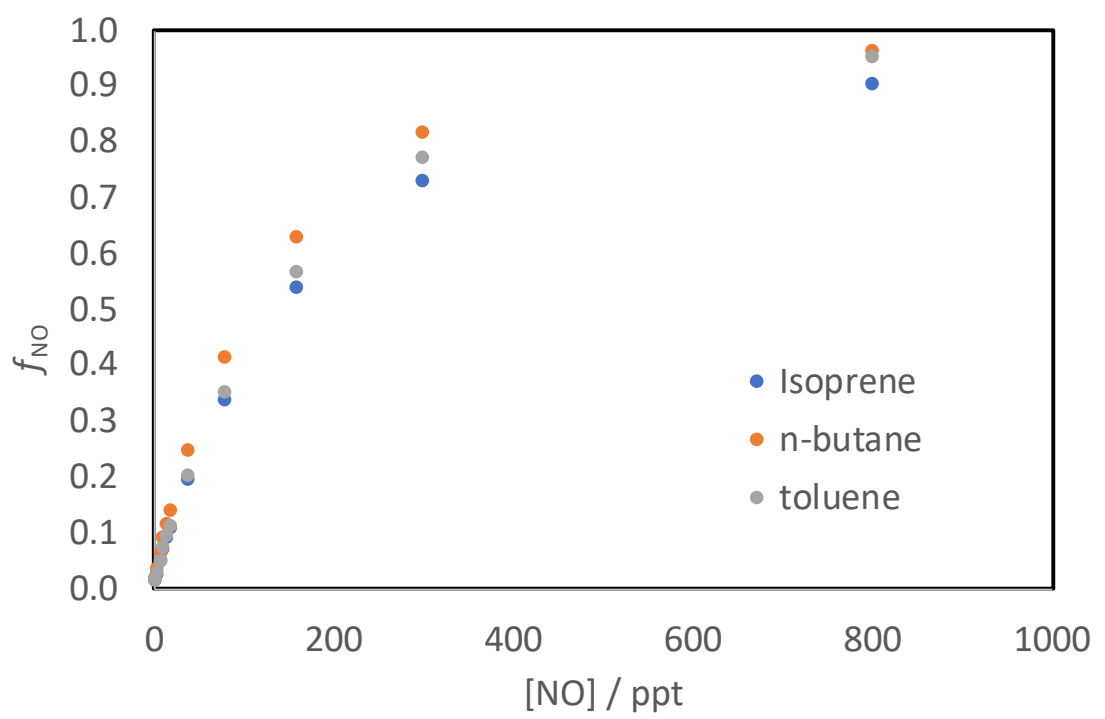

Figure S9 Variation of $f_{\mathrm{NO}}$ as a function of [NO] for the peroxy radicals formed in the initial $\mathrm{OH}$-oxidation step of isoprene, $\mathrm{n}$ butane and toluene.

\section{GEOS-Chem Modeling}

GEOS-Chem version 11-01 (http://wiki.seas.harvard.edu/geos-chem/index.php/GEOSChem_v11-01) with the inclusion of the aromatic component of RACM2 (regional atmospheric chemistry mechanism 2 ) was run nested at $0.25 \times 0.3125$ degree resolution, with $4 \times 5$ degree boundary conditions using GEOS-FP meteorology. The NO emissions were added via the default MIX emission inventory, which required a $0.9 x$ multiplier on the total daily emissions to match observations from the APHH summer campaign. The diurnal scale factor was considerably steeper than the default GEOS-Chem NO diurnal, with a day-time scale factor on the order of $1.7 x$ and a $0.25 x$ night-time multiplier. 

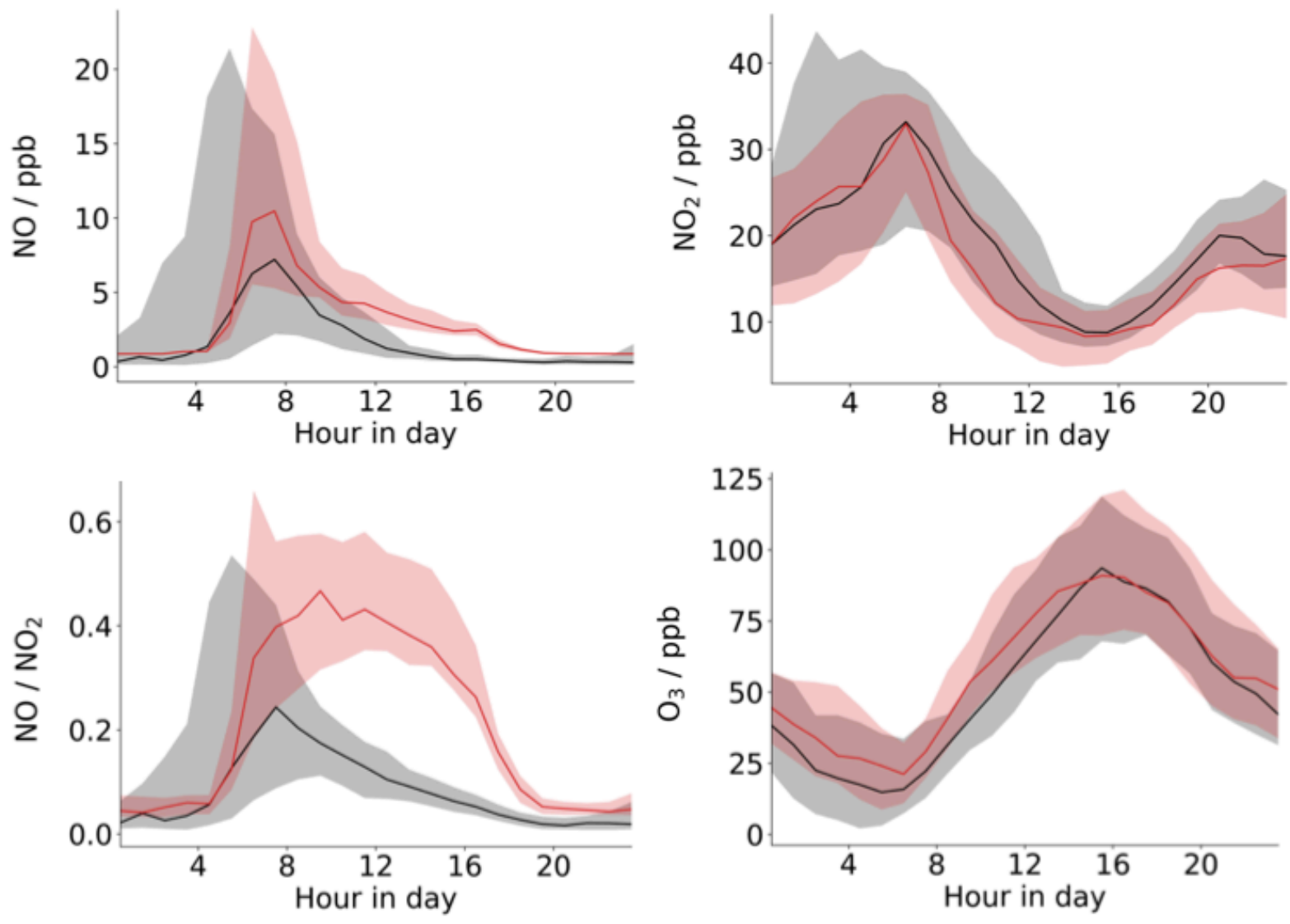

213

Figure $\mathrm{S} 10$ GEOS-Chem model output for $\mathrm{NO}, \mathrm{NO}_{2}, \mathrm{O}_{3}$ and the $\mathrm{NO} / \mathrm{NO} 2$ ratio.

While the model is able to match the observed total $\mathrm{NO}_{\mathrm{x}}$ concentration, it cannot match the observed [NO] or $\mathrm{NO}$ to $\mathrm{NO}_{2}$ ratio (Figure S10). The model over predicts $\mathrm{NO}$ and under predicts $\mathrm{NO}_{2}$. The model does a good job of replicating the $\mathrm{O}_{3}$ concentration and observed $\mathrm{NO}_{2}$ values. As such with the chemistry currently in the model there is very little flexibility available to appreciably change this ratio.

\section{References}

